\title{
Heavy Metals Distribution in Fractioned River Sediments - Case Study: Shafaroud River-South West of Caspian Sea
}

\author{
Raziyeh Lak, Mohsen Saeedi, and Ali Vosoogh
}

\begin{abstract}
Heavy metal contamination of the environmental aria has attracted a great deal of world-wide attention due to their non-biodegradable nature, long-biological half-lives for elimination from the body, their accumulation in the food chain will have a significant effect on human health in the long term.

The objectives of this study were (1) determine the physical characteristics (sediment size) of surface sediments in Shafaroud, Iran, (2) determine the relation between physical characteristics (grain size) with heavy metals pollution by using cluster analysis and multivariate statistical techniques. Distribution of total concentration of heavy metals are different in fractioned sediments. Metals that have more abundance in particles less than $38 \mu \mathrm{m}$ (clay and silt) like $\mathrm{Cu}, \mathrm{Zn}$ and $\mathrm{Mn}$ originated from anthropogenic source from sea water that attracted to fine minerals. Other metals like $\mathrm{Cr}$ that have more abundance in gravel and sand particles (particles grate than 63 $\mu \mathrm{m})$ related to natural sources. Also, these metals are found in river's placers.
\end{abstract}

Index Terms-Heavy metal, river sediment, Caspian sea, fractioned.

\section{INTRODUCTION}

Heavy metal contamination of the environmental aria has attracted a great deal of world-wide attention due to their non-biodegradable nature, long-biological half-lives for elimination from the body, their accumulation in the food chain will have a significant effect on human health in the long term [1]-[3].

Surface sediments are most vulnerable to various pollution including heavy metals due to their ease of access for the disposal of urban and industrial wastewater. Most of heavy metals in aquatic systems are bound to sediments and suspended particulate matter [4]-[7]. Therefore sediment quality has been recognized as an important environmental indicator of water pollution [8], [9] because sediments are the main sink for various pollutants, including metals discharged into the environment [10]-[13]. Also, in order to develop effective aquatic fresh water quality strategies, an in-depth understanding of the factors that affect metal desorption from

Manuscript received July 24, 2014; revised September 20, 2014. This work was supported in part by the Geological Survey of Iran (GSI).

Raziyeh Lak is with Research Institute of Geological Sciences, Geology Survey of Iran (e-mail: lak_ir@yahoo.com).

Mohsen Saeedi is with Environmental Research Laboratory, Department of Water and Environmental and Engineering, School of Civil Engineering, Iran University of Science and Technology, P.O. Box 16765-163, Narmak, Tehran, Iran (e-mail: msaeedi@iust.ac.ir).

Ali Vosoogh is with the Department of Hydraulics and Environment, School of Civil Engineering, Iran University of Science and Technology, P.O. Box 16765-163, Narmak, Tehran, Iran (e-mail: Ali_vosoogh@iust.ac.ir). sediment and the nature of the adsorption and desorption processes is essential.

Based on previous studies and reports, these factors are: Sediment size [14]-[19], Sediment composition [19], [20], Cation exchange Capacity [15], Temperature [21], [22], pH [4], [23], [24], Redox condition[4], [23]-[33], Oxic- Anoxic condition[34], Salinity [35]-[37],Organic matter [3], [4], [14], [38]-[40], Bacterial activity [41]-[43].

The objectives of this study were 1) determine the physical characteristics (sediment size) of surface sediments in Shafaroud river, Iran, 2) determine the distribution of total heavy metals concentration in different river sediment size.

\section{MAterial AND MEthodS}

\section{A. Study Area}

The study area was south west of Caspian Sea the most important rivers that have been located within Gilan province (Fig. 1). Its catchment area is about $14041 \mathrm{~km} 2$ and is located between $50^{\circ} 36^{\prime} 00^{\prime \prime}$ and $48^{\circ} 34^{\prime} 00^{\prime \prime}$ E longitude and $38^{\circ} 27^{\prime}$ $00^{\prime \prime}$ and $36^{\circ} 34^{\prime} 00^{\prime \prime} \mathrm{N}$ latitude.

According to Iran Metrological Organization reports, Gilan province is the rainiest provinces in Iran with average $580 \mathrm{~mm}$ per year. Diversity of plant and animal species has been visible in Gilan province [44].

The agricultural geography of Gilan can be divided into coastal lowlands; plain areas with rice, tea and tobacco cultivation; foothill lands with tea cultivation and fruit trees and mountainous lands with grains as well as forage plants; based on the altitude parameter. However, the most important agricultural activity centers are the coastal low lands, lands and plain areas situated at less than 100 elevation at open sea level [45].

An important part of massive and humid woods of the Caspian Sea water drainage area [46].

Moreover, water resources of the Gilan region are rain and snow falls. The probability of snowfall at all months of the year is quite high. At hydrological side, the rate of rain is higher in all rivers.

The important and interesting particularities of Gilan Rivers include a massive hydrographic network with a large number of rivers as well as large range of water quantity in the rivers, shortness of the flow and flooding condition at their place of origin. The inundating rivers, by transporting circular stone pieces and blocks and by under-washing the ridges overlooking the farms and orchards, threaten the cultivated areas and gardens. Submit your manuscript electronically for review.

The uncontrolled floods courses can result in water 
penetration, weight increase as well as sliding condition of soil masses. These conditions could cause the houses located at the foothills to crack or to fall down, [47].

Moreover, According to the Iran Ministry of Industries and Mines data 60 active and 19 abounded mines are located in study area That produce heavy metals such as $\mathrm{Fe}, \mathrm{Pb}, \mathrm{Zn}$, Ti and so on, coal mining activities is as of the examples of mine type in the catchment area.

There are 703 major factories including food industries, chemical industries, plastics and tires, textile, wood and paper machines located in the study area [48].

Shafaroud is the latest River that flows directly into the Caspian sea. This river originates from elevations over than 2800 meters from west to east .The river is constantly full of water and the length of its path from source to sea is about 48 $\mathrm{km}$.

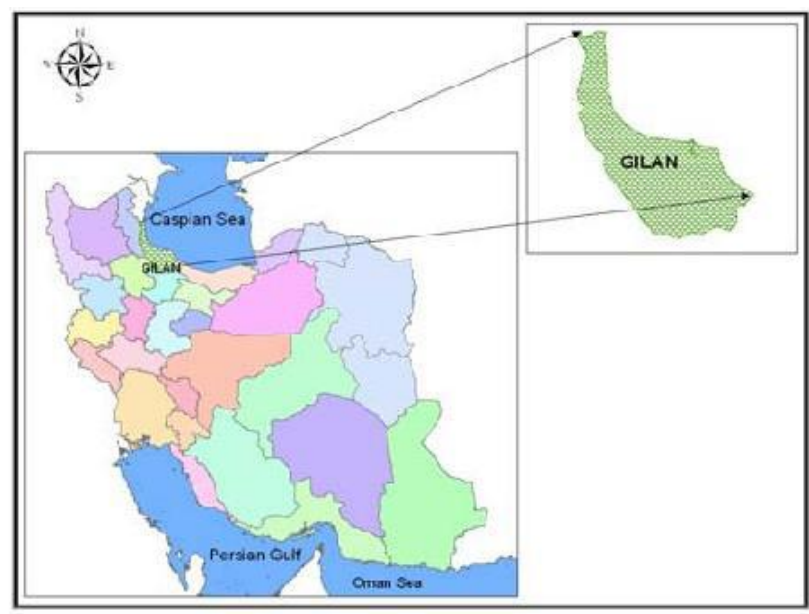

Fig. 1. Study area located in Gilan province in Northern Iran, south of Caspian sea.

\section{B. Sample Collection and Preparation}

Primarily, according to the purposes of this research, the geological map of study area has been used. For selection of sampling stations (sampling network), has been tried these stations located on different geological formations. Geographic coordinate of Surface sediment sampling stations have been illustrated in Table I.

TABLE I: GEOGRAPHIC COORDINATE OF SURFACE SEDIMENT SAMPLING STATIONS

\begin{tabular}{|c|c|c|}
\multicolumn{2}{|c|}{ STATIONS } \\
\hline \multirow{2}{*}{ Station No. } & \multicolumn{2}{|c|}{ Geographic coordinate } \\
\cline { 2 - 3 } & $\mathrm{X}$ & $\mathrm{Y}$ \\
\hline 1 & 39.337447 & 41.62540 \\
\hline 2 & 37.53016 & 49.10350 \\
\hline 3 & 37.53880 & 48.91876 \\
\hline 4 & 37.50138 & 48.79193 \\
\hline
\end{tabular}

Shafaroud's surface sampling size locations has been shown in Fig. 2.

According to above steps, 4 surface sediment samples were taken from the Shafaroud River, Gilan province.

From upstream to estuaries selected for sampling during June 2013.

Samples were collected by Ekman type grab sampler. All samples were transferred to the laboratory in sealed plastic bags under 0 to $4{ }^{\circ} \mathrm{C}$.

Each sediment sample was divided randomly into two part to allow for grain-size and geochemical analysis.

Grain-size analysis was carried out using wet standard sieving methods for particles larger than $38 \mu$ mby using sieve shaker (Analysette 3 Pro, Fritsch)and laser grain size analyzer for particles less than $38 \mu \mathrm{m}$ (Analysette 22, Fritsch) at the Research center for applied geology, Geological Survey of Iran, Sedimentology Laboratory.

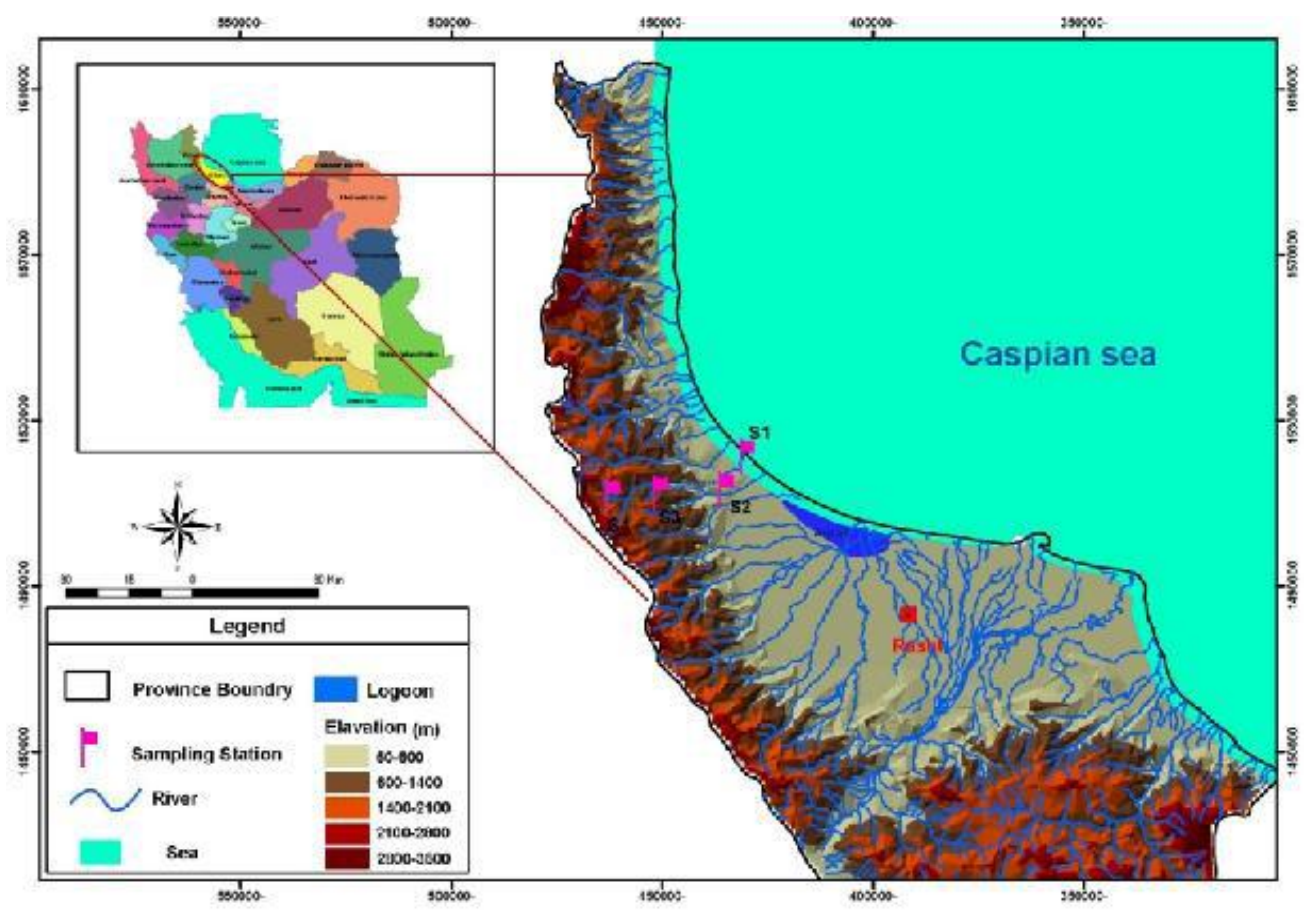

Fig. 2. Location of sediment sampling stations in Shafaroud river.

\section{Laboratory Analysis}

\section{1) Grain size analysis}

The 4 collected rivers samples were separated into ten particle size ranges as follow: $<38 \mu \mathrm{m}, 38-63 \mu \mathrm{m}, 63-125 \mu \mathrm{m}$, $125-250 \mu \mathrm{m}, 250-500 \mu \mathrm{m}, 500 \mu \mathrm{m}-1 \mathrm{~mm}, 1-2 \mathrm{~mm}, 2-4 \mathrm{~mm}$, $4-8 \mathrm{~mm}$ and $>8 \mathrm{~mm}$.

Grain size analysis was done by wet sieve shaker. But 
according to purposes of this research, only six particle Size ranges $(<38 \mu \mathrm{m}, \quad 38-63 \mu \mathrm{m}, \quad 63-125 \mu \mathrm{m}, \quad 125-250 \mu \mathrm{m}$, $250-500 \mu \mathrm{m}, 500 \mu \mathrm{m}-1 \mathrm{~mm})$ were selected for chemical analysis.

\section{2) Chemical analysis}

a) Preparation of samples and digestion

Homogenous and powdered samples, bulk and fractional, $(0.5 \mathrm{~g})$ are treated with an oxidizing mixture $\left(\mathrm{HNO}_{3} / \mathrm{HCl} /\right.$ HF) according to ASTM test methods (ASTM-D4698-92-2013).

Metal concentrations (Fe, $\mathrm{Al}, \mathrm{Ca}, \mathrm{Mn}, \mathrm{Cu}, \mathrm{Zn}, \mathrm{Cr}, \mathrm{Pb}, \mathrm{Ni}$, $\mathrm{Cd}, \mathrm{V}$ and $\mathrm{Co}$ ) in solution are determined by an

Inductively Coupled Plasma/Optical Emission Spectroscopy (ICP-OES-730).

Standard quality control procedures were followed to maintain accuracy and reliability of the laboratory analysis.

Precision and accuracy of metal analyses and the digestion procedure was monitored using internal standards, certified reference material (standard sediment sample-GBW01-12) and quality control blanks.

\section{RESULTS AND DISCUSSION}

\section{A. Sediment Particle Size and Metal Pollution}

Total metal concentrations ( $\mathrm{Fe}, \mathrm{Al}, \mathrm{Ca}, \mathrm{Mn}, \mathrm{Cu}, \mathrm{Zn}, \mathrm{Cr}, \mathrm{Pb}$, $\mathrm{Ni}, \mathrm{Cd}, \mathrm{V}$ and $\mathrm{Co}$ ) and statistical parameters of 4 samples across the six particle size ranges, $<38 \mu \mathrm{m}, 38-63 \mu \mathrm{m}$, $63-125 \mu \mathrm{m}, 125-250 \mu \mathrm{m}, 250-500 \mu \mathrm{m}$ and $500-1000 \mu \mathrm{m}$ are presented in Table II.

TABLE II: TOTAL HEAVy METAL CONCENTRATION IN FRACTIONED SEDIMENTS

\begin{tabular}{|c|c|c|c|c|c|c|c|c|c|c|}
\hline \multirow[t]{2}{*}{ Sampling station } & \multirow[t]{2}{*}{ Sediment $\operatorname{size}(\mu \mathrm{m})$} & \multicolumn{9}{|c|}{ Total concentration $(\mathrm{ppm})$} \\
\hline & & $\mathrm{Cu}$ & $\mathrm{Zn}$ & $\mathrm{Cr}$ & $\mathrm{Fe}$ & $\mathrm{Mn}$ & $\mathrm{Pb}$ & $\mathrm{Ni}$ & $\mathrm{Cd}$ & $\mathrm{Al}$ \\
\hline \multirow{6}{*}{1} & $<38$ & 52.06 & 183.60 & 218.04 & 56488.57 & 1371.43 & 17.34 & 110.15 & 1.27 & 85162.98 \\
\hline & $38-63$ & 51.66 & 187.47 & 205.72 & 61756.84 & 1290.11 & 35.00 & 109.04 & 1.12 & 83635.68 \\
\hline & $63-125$ & 54.46 & 141.51 & 308.41 & 67219.91 & 921.31 & 14.42 & 118.04 & 1.35 & 99379.06 \\
\hline & $125-250$ & 47.53 & 136.33 & 500.14 & 69530.39 & 1085.43 & 11.50 & 107.88 & 0.05 & 73764.50 \\
\hline & $250-500$ & 46.68 & 94.22 & 620.32 & 72033.99 & 1126.39 & 8.38 & 85.05 & 0.05 & 72823.69 \\
\hline & $500-1000$ & 53.80 & 80.72 & 264.90 & 62086.04 & 938.96 & 8.90 & 71.89 & 0.05 & 79468.87 \\
\hline \multirow{6}{*}{2} & $<38$ & 49.24 & 182.02 & 219.46 & 61212.16 & 1419.08 & 16.42 & 120.23 & 0.05 & 88302.01 \\
\hline & $38-63$ & \\
\hline & $63-125$ & 52.93 & 153.82 & 327.85 & 73243.12 & 978.31 & 12.21 & 114.48 & 1.54 & 105923.00 \\
\hline & $125-250$ & 46.63 & 154.63 & 777.26 & 91631.46 & 1207.47 & 14.65 & 166.08 & 1.31 & 71771.71 \\
\hline & $250-500$ & 45.14 & 134.28 & 874.05 & 88542.91 & 1180.50 & 12.03 & 166.45 & 1.27 & 68301.27 \\
\hline & $500-1000$ & 47.99 & 93.04 & 613.41 & 73317.69 & 996.67 & 11.34 & 139.19 & 0.05 & 69953.47 \\
\hline \multirow{6}{*}{3} & $<38$ & 62.00 & 194.87 & 271.97 & 65015.25 & 1388.41 & 18.90 & 152.86 & 1.36 & 94650.68 \\
\hline & $38-63$ & 43.87 & 109.74 & 222.21 & 60393.88 & 900.36 & 16.54 & 109.60 & 0.05 & 72183.67 \\
\hline & $63-125$ & 55.50 & 117.07 & 461.80 & 82222.56 & 1151.78 & 22.90 & 140.81 & 1.82 & 89535.06 \\
\hline & $125-250$ & 52.96 & 115.38 & 918.50 & 90064.38 & 1247.25 & 14.84 & 161.16 & 0.05 & 66975.99 \\
\hline & $250-500$ & 51.15 & 108.40 & 860.74 & 81454.66 & 1155.57 & 15.59 & 156.03 & 0.05 & 67024.24 \\
\hline & $500-1000$ & 50.15 & 94.76 & 658.40 & 72855.91 & 1042.53 & 11.82 & 172.69 & 0.05 & 68079.47 \\
\hline \multirow{6}{*}{4} & $<<38$ & 67.27 & 375.86 & 339.59 & 68645.64 & 944.30 & 24.01 & 215.15 & 1.50 & 81539.68 \\
\hline & $38-63$ & 53.26 & 253.29 & 254.86 & 61528.91 & 988.13 & 26.87 & 147.00 & 0.05 & 72311.72 \\
\hline & $63-125$ & 53.57 & 175.39 & 197.98 & 52201.78 & 711.40 & 15.80 & 101.09 & 1.02 & 72893.05 \\
\hline & $125-250$ & 45.36 & 133.28 & 370.08 & 56255.30 & 747.91 & 14.61 & 155.15 & 0.05 & 65123.98 \\
\hline & $250-500$ & 46.82 & 101.32 & 365.70 & 56941.22 & 769.26 & 13.56 & 193.31 & 0.05 & 65218.51 \\
\hline & $500-1000$ & 48.09 & 92.65 & 323.35 & 56191.19 & 756.21 & 13.42 & 194.06 & 0.05 & 66300.82 \\
\hline \multicolumn{2}{|c|}{ Earth crust content } & 47.00 & 83.00 & 83.00 & 46500.00 & 1000.00 & 16.00 & 58.00 & 0.13 & 80500.00 \\
\hline
\end{tabular}

\section{1) $<38 \mu m$}

Total concentrations of all metals are higher than those of earth's crust except for Mn in sampling station 4.

\section{2) $38-63 \mu \mathrm{m}$}

Total concentrations of all metals are higher than those of earth's crust content except for $\mathrm{Cu}$ (sampling station 3), Mn(sampling stations 3 and 4), Cd(sampling stations 3 and 4) and $\mathrm{Al}$ (sampling stations 3 and 4 ).

\section{3) $63-125 \mu \mathrm{m}$}

Total concentrations of all metals are higher than those of earth's crust content except for Mn (sampling stations 1, 2 and 4$), \mathrm{Pb}$ (sampling stations 1,2 and 4 ) and $\mathrm{Al}$ (sampling stations 4).

\section{4) $125-250 \mu \mathrm{m}$}

Total concentrations of all metals are higher than those of earth's crust content except for $\mathrm{Cu}$ (sampling stations 2 and 4), Mn(sampling station 4), $\mathrm{Pb}$ (sampling station1), $\mathrm{Cd}$ (sampling stations 1,3 and 4 ) and $\mathrm{Al}$ (sampling stations 3 and 4).

\section{5) $250-500 \mu m$}

Total concentrations of all metals are higher than those of earth's crust content except for $\mathrm{Cu}$ (sampling stations 1 and 4), $\mathrm{Mn}$ (sampling station 4), $\mathrm{Pb}$ (sampling station1, 2, 3 and 4), $\mathrm{Cd}$ (sampling stations 1,3 and 4) and $\mathrm{Al}$ (sampling stations 2, 3 and 4).

\section{6) $500-1000 \mu m$}

Total concentrations of all metals are higher than those of earth's crust content except for $\mathrm{Zn}$ (sampling station 1), $\mathrm{Mn}$ (sampling station 4), $\mathrm{Pb}$ (sampling station1, 2, 3 and 4), $\mathrm{Cd}$ (sampling stations 1, 2, 3 and 4) and $\mathrm{Al}$ (sampling stations1, 2, 3 and 4). 
Total metal concentration in sediment particle fractioned as percent is presented in Table III.

According to Table III, higher level of metal concentrations in percent were found in particle less than 125 $\mu \mathrm{m}$, except for $\mathrm{Cr}, \mathrm{Fe}$ and $\mathrm{Ni}$.
The minimum content of metals were detected in particles less than $125 \mu \mathrm{m}$ except for $\mathrm{Zn}, \mathrm{Pb}$ and $\mathrm{Cd}$. For $\mathrm{Cu}, \mathrm{Cr}$, Fe, $\mathrm{Mn}, \mathrm{Ni}$ and $\mathrm{Al}$ minimum content were found in particles larger than $125 \mu \mathrm{m}$.

TABLE III: Total METAl CONCENTRATION IN SEDIMENT PARTIClE FRACTIONED AS PERCENT

\begin{tabular}{|c|c|c|c|c|c|c|c|c|c|}
\hline Particle Size- $\mu \mathrm{m}$ & $\mathrm{Cu}$ & $\mathrm{Zn}$ & $\mathrm{Cr}$ & $\mathrm{Fe}$ & $\mathrm{Mn}$ & $\mathrm{Pb}$ & $\mathrm{Ni}$ & $\mathrm{Cd}$ & $\mathrm{Al}$ \\
\hline$<38$ & $\mathbf{1 9 . 5 7}$ & $\mathbf{2 7 . 4 3}$ & 10.31 & 15.90 & $\mathbf{2 1 . 0 7}$ & 20.66 & 18.66 & 23.07 & 19.64 \\
\hline $38-63$ & $\mathbf{1 2 . 6 3}$ & 16.13 & $\mathbf{6 . 7 1}$ & $\mathbf{1 1 . 6 2}$ & $\mathbf{1 3 . 0 7}$ & $\mathbf{2 1 . 1 3}$ & $\mathbf{1 1 . 4 0}$ & 10.60 & $\mathbf{1 2 . 8 1}$ \\
\hline $63-125$ & 18.37 & 17.22 & 12.74 & 17.39 & 15.47 & 17.61 & 14.79 & $\mathbf{2 8 . 5 0}$ & $\mathbf{2 0 . 6 6}$ \\
\hline $125-250$ & 16.34 & 15.81 & 25.22 & $\mathbf{1 9 . 4 5}$ & 17.63 & 14.98 & 18.40 & 14.02 & 15.59 \\
\hline $250-500$ & 16.11 & 12.84 & $\mathbf{2 6 . 7 4}$ & 18.91 & 17.40 & 13.36 & $\mathbf{1 8 . 7 3}$ & 13.84 & 15.35 \\
\hline $500-1000$ & 16.98 & $\mathbf{1 0 . 5 8}$ & 18.28 & 16.73 & 15.36 & $\mathbf{1 2 . 2 6}$ & 18.02 & $\mathbf{9 . 9 8}$ & 15.94 \\
\hline
\end{tabular}

- The highest and lowest values are highlighted

\section{CONCLUSION}

Distribution of total concentration of heavy metals are different in fractioned sediments. Metals that have more abundance in particles less than $38 \mu \mathrm{m}$ (clay and silt) like $\mathrm{Cu}$, $\mathrm{Zn}$ and $\mathrm{Mn}$ originated from anthropogenic source from sea water that attracted to fine minerals.

Other metals like $\mathrm{Cr}$ that have more abundance in gravel and sand particles (particles grate than $63 \mu \mathrm{m}$ ) related to natural sources. Also, these metals are found in river's placers.

\section{REFERENCES}

[1] A. Kabata-Pendias and H. Pendias, Trace Elements in Soils and Plants, 2nd ed. Florida CRC Press, Boca Raton, 1992.

[2] R. Radha, R. M. Tripathi, K. A. Vinod, A. P. Sathe, R. N. Khandekar, and K. S. V. Nambi, "Assessment of $\mathrm{Pb}, \mathrm{Cd}, \mathrm{Cu}$, and $\mathrm{Zn}$ exposures of 6- to 10-year-old children in Mumbai," Environmental Research, vol. 80, pp. 215-221, 1997.

[3] X. D. Li, S. L. Lee, S. C. Wong, W. Z. Shi, and I. Thorntonc, "The study of metal contamination in urban soils of Hong Kong using a GIS-based approach," Environmental Pollution, vol. 129, issue 1, pp. 113-124, 2004.

[4] M. Chabukdhara and A. Nema, "Assessment of heavy metal contamination in Hindon River sediments: A chemometric and geochemical approach," Chemosphere, no. 87, pp. 945-953, 2012.

[5] W. Calmano, J. Hong, and U. Forstner, "Binding and mobilization of heavy metals in contaminated sediments affected by $\mathrm{pH}$ and redox potential," Water Science Technology, vol. 28, pp. 8-9, pp. 223-235, 1993.

[6] C. K. Jain, "Metal fractionation study on bed sediments of River Yamuna, India," Water Research, vol. 38, issue 3, pp. 569-578, 2004.

[7] P. Rath, U. C. Panda, D. Bhatta, and K. C. Sahu, "Use of sequential leaching, mineralogy, morphology and multivariate statistical technique for quantifying metal pollution in highly polluted aquatic sediments-a case study: Brahmani and Nandira Rivers, India," Journal of Hazardous Material, vol. 163, issue 2-3, pp. 632-644, 2009.

[8] M. Saeedi, L. Y. Li, A. R. Karbassi, and A. J. Zanjani, "Sorbed metals fractionation and risk assessment of release in river sediment and particulate matter," Environmental Monitoring and Assessment, no. 185, pp. 1737-1754, 2013.

[9] B. Larsen and A. Jensen, "Evaluation of the sensitivity of sediment monitoring stationary in pollution monitoring," Marine Pollution Bulletin., vol. 20, pp. 556-560, 1989.

[10] J. M. Casas, H. Rosas, M. Solé, and C. Lao, "Heavy metals and metalloids in sediments from the Llobregat basin," Spain Environmental Geology, no. 44, pp. 325-332, 2003.

[11] M. Dassenakis, M. Scoullos, and A. Gaitis, "Trace metals transport and behavior in the Mediterranean estuary of Acheloos river," Marine Pollution Bulletin, no. 34, pp. 103-111, 1997.

[12] N. F. Y. Tam and W. S. Wong, "Spatial variation of metals in surface sediments of Hong Kong mangrove swamps," Environmental Pollution, no. 110, pp. 195-205, 2000.
[13] R. Bettinetti, C. Giarei, and A. Provini, "Chemical analysis and sediment toxicity bioassays to assess the contamination of the River Lambro (Northern Italy).Arch," Environmental Contamination Toxicology, vol. 45, issue 1, pp. 72-78, 2003.

[14] K. P. Singh, D. Mohan, V. K. Singh, and A. Malik, "Studies on distribution and fractionation of heavy metals in Gomti river sediments-a tributary of the Ganges," Journal Hydrology, vol. 312, issue 1-4, pp. 14-27, 2005.

[15] U. Fostrtner and G. T. W. Wittmann, Metal Pollution in the Aquatic Environment, Berlin, Springer-Verlag, 1981.

[16] A. J. Horowitz, "A primer on trace-metal sediment chemistry," US Geological Survey Water Supply Paper, U.S. Government Printing Office, 1985.

[17] W. Salomons and U. Forstner, Metals in the Hydrocycle, Springer-Verlag, 1984.

[18] F. Pagnanelli, E. Moscardini, V. Giuliano, and L. Toro, "Sequential extraction of heavy metals in river sediments of an abandoned pyrite mining area: pollution detection," Environmental Pollution, vol. 132, issue 2, pp. 189-201, 2004.

[19] D. Guven and G. Akinci, "Effect of sediment size on bioleaching of heavy metals from sediment of Izmir Inner Bay," Journal of Environmental Sciences, vol. 25, issue 9, pp. 1784-1794, 2013.

[20] C. Gunawardana, P. Egodawatta, and A. Goonetilleke, "Role of particle size and composition in metal adsorption by solids deposited on urban road surfaces," Environmental Pollution, no. 184, pp. 44-53, 2014.

[21] C. F. Balasoiu, G. J. Zagury, and L. Deschenes, "Partitioning and speciation of chromium, copper, and arsenic in CCA-contaminated soils: influence of soil composition," The Science of the Total Environment., no. 280, pp. 239-255, 2001.

[22] L. Tsai, K. K.-C. Yu, S. Chen, and P. Kung, "Effect of temperature on removal of heavy metals from contaminated river sediments via bioleaching," Water Research, vol. 37, no. 10, pp. 2449-57, 2013.

[23] G. M. Gadd, "Heavy metal pollutants: Environmental and biotechnological aspects," Applied Microbiology, pp. 321-334, 2009.

[24] U. Forstner, W. Ahlf, and W. Calmano, "Studies on the transfer of heavy metals between sedimentary phases with a multi-chamber device: Combined effects of salinity and redox variation," Marine chemistry, no. 28, pp. 1-3, 1989.

[25] M. M. Benjamin and J. O. Leckie, "Mutiple-site adsorption of Cd, Cu, $\mathrm{Zn}$, and $\mathrm{Pb}$ on amorphous iron oxyhydroxide," Journal of Colloid and Interface Science., no. 79, pp. 209-211, 1981

[26] T. Z. Guo, R. D. de Laune, and W. H. Patrick, "The influence of sediment redox chemistry on chemically active forms of Arsenic, Cadmium, Chromium and Zinc in estuarine sediment," Environmental International, vol. 23, issue 3, pp. 305-316, 1997.

[27] W. H. Patrick and R. D. de Laune, "Chemical and biological redox systems affecting nutrient availability in coastal wetlands," Geosciences Managment, no. 18, pp. 131-137, 1977.

[28] P. H. Masscheleyn, R. D. de Laune, and W. H. Patrick, "Arsenic and selenium chemistry as affected by sediment redox potential and $\mathrm{pH}$," Journal of Environmental Quality, no. 20, pp. 522-527, 1991.

[29] W. H. Patrick and A. Jugsujinda, "Sequential reduction and oxidation of inorganic nitrogen, manganese and iron in flooded soil," Soil Science Society American Journal, no. 56, pp. 1071-1073, 1992.

[30] M. Kerner and K. Wallman, "Remobilization events involving Cd and $\mathrm{Zn}$ from intertidal mud flat sediments in the Elbe Estuary during the 
tidal cycle," Estuarine Coastal and Shelf Science, no. 35, pp. 371-393, 1992.

[31] D. B. Levy, K. A. Barbarick, E. G. Siemer, and L. E. Sommers, "Distribution and partitioning of trace metals in contaminated soils near Leadville, Colorado," Journal of Environment Quality, no. 21, pp. 185-195, 1992.

[32] J. H. Pardu and W. H. Patrick, "Changes in metal speciation following alteration of sediment redox status," in Metal Contaminated Aquatic Sediments, H. E. Allen, 1995, pp. 169-185.

[33] T. Mansfeldt, "Redox potential of bulk soil and soil solution concentration of nitrate, manganese, iron, and sulfate in two Gleysols," Journal of Plant Nutrient Soil Science, vol. 167, issue 1, pp. 7-16, 2004.

[34] A. Violante, P. M. Huang, and G. M. Gadd, Biophysico-Chemical Processes of Heavy Metals and Metalloids in Soil Environments, John Wiley \& Sons, INC., 2008.

[35] M. A. A. Paalman, C. H. van der Weijden, and J. P. G. Loch, "Sorption of cadmium on suspended matter under estuarine conditions: competition and complexation with major seawater ions," Water, Air, and Soil Pollution, vol. 73, issue 1, pp. 49-60, 994.

[36] V. Hatje, T. E. Payne, D. M. Hill, G. McOrist, G. F. Birch, and R. Szymczak, "Kinetics of trace element uptake and release by particles in estuarine waters: effects of $\mathrm{pH}$, salinity, and particle loading," Environment International, no. 29, pp. 619-629, 2003.

[37] U. Fostrtner and G. T. W. Wittmann, Metal Pollution in the Aquatic Environment, Springer-Verlag, Berlin, 1985.

[38] I. Saulnier and A. Mucci, "Trace metal remobilization following the resuspension of estuarine sediments: Saguenay Fjord, Canada," Applied Geochemistry, no. 15, pp. 191-210, 2000.

[39] X. Li, Z. Shen, O. W. H. Wai, and Y.-S. Li, "Chemical partitioning of heavy metal contaminants in sediments of the Pearl River Estuary," Chemistry Special bioavailibility, vol. 12, issue 1, pp. 17-25, 2000.

[40] T. Zoumis, A. Schmidt, L. Grigorova, and W. Calmano, "Contaminants in sediments: remobilization and demobilization," Science of the Total Environment, no. 266, pp. 195-202, 2001.

[41] W. Fan, W.-X. Wang, J. Chen, X. Li, and Y.-F. Yen, "Cu, Ni and Pb speciation in surface sediments from a contaminated bay of northern China," Marine Pollution Bulletin, no. 44, pp. 816-832, 2002.

[42] K. Bosecker, "Bioleaching: Metal solubilization by microorganisms," FEMS Microbiological Review, vol. 20, pp. 591-604, 1997.

[43] C. Gounou, N. Bousserrhine, G. G. Varrault, and J. Mouchel, "Influence of the iron-reducing bacteria on the release of heavy metals in anaerobic river sediment," Water Air Soil Pollution, vol. 212, issue 1-4, pp. 123-139, 2010.

[44] Gilan province characteristics, master plan study, Geological Survey of Iran, 2014.

[45] F. Asadian, A. Arzjani, and M. Varavipour, "Changes of microenvironment in Gilan city due to landsides," Carpathian Journal of Earth and Environmental Sciences, no. 1, pp. 93-102, 2010.

[46] M. Zaheri, "Gilan forests," Gilan Book, Rasht, Iran, pp. 195-197, 2001.

[47] I. Ibrahim, "The Book of Gilan," Iran Researchers Group, Iran, pp. $35-44,2001$.

[48] A. Jamshidi and M. Saeedi, "Metal pollution assessment and multivariate analysis in sediment of Anzali international wetland," Environmental Earth Science, vol. 70, pp. 1791-1890, 2013.

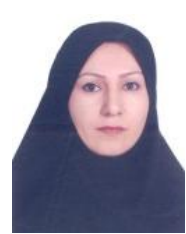

Raziyeh Lak received the $\mathrm{PhD}$ and M.S degrees in sedimentology. She is an assistant professor in the Research Institute for Earth Sciences, Iran.

She is also the president of Geosciences Committee Iranian National Commission for UNESCO.

Her research areas are in sedimentology, marine geology paleogeolimnology, geochemistry, hydrogeochemistry, coastal geomorpholog.

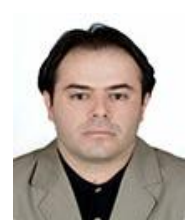

Mohsen Saeedi graduated with the $\mathrm{PhD}$ degree in civil-environmental engineering. $\mathrm{He}$ is an associate professor in Civil School, Iran University of Science \& Technology, Iran.

$\mathrm{He}$ is also the visiting associate professor at the University of British Columbia. His research areas are geochemistry, petroleum hydrocarbons pollution in soil sediment, fate of heavy metals in aquatic environment.

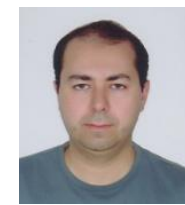

Ali Vosoogh is a PhD candidate of civil-water engineering in Iran University of Science \& Technology, Iran.

$\mathrm{He}$ is also a research assistant at Iran University of Science \& Technology. His research areas are in geochemistry, hydrogeochemistry, water \& waste water treatment, water and soil pollution, sediment quality. 